\section{Response of Bedding Plants to Saline Water Irrigation}

\author{
Genhua Niu ${ }^{1}$ and Denise S. Rodriguez \\ Texas AgriLife Research and Extension Center at El Paso, Texas A\&M \\ University, 1380 A\&M Circle, El Paso, TX 79927
}

Terri Starman

Department of Horticultural Science, Texas A\&M University, College Station, TX 77843-2133

Additional index words. landscape irrigation, salinity tolerance, water reuse

\begin{abstract}
Bedding plants are extensively used in urban landscapes. As high-quality water supply becomes limited in many parts of the world, the use of recycled water with high salt levels for landscape irrigation is being encouraged. Therefore, information on salt tolerance of bedding plants is of increasing importance. Two experiments were conducted, one in a $25 \%$ light exclusion shadehouse in summer (Expt. 1) and the other in a greenhouse in winter (Expt. 2). Plants were irrigated with saline solution at electrical conductivities of $0.8,2.8,4.0,5.1$, or $7.4 \mathrm{dS} \cdot \mathrm{m}^{-1}$ created by adding $\mathrm{NaCl}, \mathrm{MgSO}_{4}$, and $\mathrm{CaCl}_{2}$ to tap water to simulate the composition of local reclaimed water. In Expt. 1, shoot dry weight (DW) at the end of the experiments was reduced in all species at $7.4 \mathrm{dS} \cdot \mathrm{m}^{-1}$ compared with the control $\left(0.8 \mathrm{dS} \cdot \mathrm{m}^{-1}\right)$. The magnitude of reduction varied with species and cultivars. The salinity thresholds of irrigation water in which growth reduction occurred were $4.0 \mathrm{dS} \cdot \mathrm{m}^{-1}$ for angelonia (Angelonia angustifolia) cultivars and ornamental pepper (Capsicum annuum) 'Calico' and 4.0 to $5.1 \mathrm{dS} \cdot \mathrm{m}^{-1}$ for helenium (Helenium amarum), licorice plant (Helichrysum petiolatum), and plumbago (Plumbago auriculata). Shoot DW and growth index of ornamental pepper 'Black Pearl' and vinca (Catharanthus roseus) 'Rose' decreased linearly as salinity increased. All plants survived in Expt. 1 regardless of treatment, except for ornamental pepper 'Purple Flash'. No visual injuries were observed in Expt. 1 regardless of treatment. Leaf sodium (Na) and chlorine (CI) concentrations varied with species and treatments. Ornamental pepper 'Black Pearl' had the highest leaf $\mathrm{Cl}$ concentrations at higher salinities compared with other species and cultivars. Leaf $\mathrm{Na}$ concentrations in licorice plant and plumbago were in the range of 10 to $30 \mathrm{~g} \cdot \mathrm{kg}^{-1} \mathrm{DW}$, higher than those in other species. In Expt. 2, shoot DW was reduced by salinity treatments in ornamental pepper 'Black Pearl', plumbago, and angelonia but not in other species. The three ornamental peppers, 'Black Pearl', 'Calico', and 'Purple Flash', exhibited slight foliar injuries on some plants in Expt. 2 as a result of high salinity in the root zone in the highest salinity treatment. Ornamental pepper 'Black Pearl' was most sensitive to salinity stress. In general, the bedding plants tested in this study are moderately tolerant to salt stress and may be irrigated with saline water up to $4.0 \mathrm{dS} \cdot \mathrm{m}^{-1}$ with little reduction in aesthetical appearance.
\end{abstract}

Water shortage and poor water quality are critical issues in the Southwest and many other regions of the world. With a rapidly increasing population and diminishing water supplies, the competition for fresh water among agriculture, industry, urban, and recreational users has become intense. Use of municipal reclaimed water (also called recycled water in some states) to irrigate landscapes can conserve a substantial amount of potable water because $\approx 50 \%$ of the total municipal water consumption from May through Octo-

Received for publication 6 Oct. 2009. Accepted for publication 3 Nov. 2009.

We gratefully acknowledge the financial support from Cooperative State Research, Education and Extension Service, U.S. Department of Agriculture under Agreement No. 2005-34461-15661 and El Paso Water Utilities. We also thank Ball Horticulture for donating seeds.

${ }^{1}$ To whom reprint requests should be addressed; e-mail gniu@ag.tamu.edu. growth, and quality. Cabrera and Perdomo (2003) observed a positive correlation between relatively high leaf chlorine $(\mathrm{Cl})$ concentration and dry weight of container-grown Rosa $\times$ hybrida 'Bridal Pink' (on $R$. manetti rootstock). A number of herbaceous perennials, groundcovers, floricultural crops, and landscape woody shrubs became more compact with little visual damage when irrigated with low to moderate salinity compared with nonsaline control (Carter and Grieve, 2006; Gerhart et al., 2006; Grieve et al., 2006; Niu and Rodriguez, 2006a, 2006b; Wu et al., 2001). For landscape plants, maximizing growth is not essential and, indeed, excessive shoot vigor is often undesirable. To maintain a compact growth habit, ornamental plants traditionally have either been pruned or treated with growth regulators (Cameron et al., 2004). Therefore, reclaimed water may play an important role for landscape irrigation where the supply of high-quality water is limited. Nevertheless, the salinity tolerance range or threshold for optimal growth and quality of landscape plants needs to be identified for efficient and sustainable use of reclaimed water.

Salt tolerance of plants depends on species, climatic conditions, type of substrate or soil, and irrigation method. Although salinity levels of irrigation water were kept constant, root zone salinity increased with time, especially when peat-based substrate or clay soil was used (Miyamoto et al., 2005; Niu and Rodriguez, 2006a, 2006b). Salt accumulation in the root zone is affected by the physical and chemical properties of the substrate, plant size, and environmental conditions because these factors influence the substrate moisture content and cation exchange capacity in the root zone. Plants were more susceptible to salinity stress under sprinkler irrigation than drip irrigation as a result of direct contact with salts (Wu et al., 2001). Foliar salt injuries of a number of landscape plants irrigated with saline water were most affected during the hottest and driest periods of summer (Fox et al., 2005; Niu et al., 2007).

As more low-quality water is used for landscape irrigation, demand for salt-tolerant bedding plants will increase in arid and semiarid regions. Little information is available on salt tolerance of bedding plants. The objective of this study was to quantify the relative salt tolerance of 10 selected bedding plant species and cultivars, whose performance ranged from acceptable to excellent under limited irrigation conditions in a semiarid desert environment (Niu and Rodriguez, 2007). In the current study, the same 10 species and cultivars were irrigated with water at various salinity levels in two experiments conducted in a shadehouse (summer) or a greenhouse (winter).

\section{Materials and Methods}

Plant materials and culture. Two experiments were conducted in this study: from 5 June to 5 Sept. 2008 in a shadehouse with a shadecloth of $25 \%$ light exclusion (Expt. 1) and from 19 Dec. 2008 to 10 Feb. 2009 in 
a greenhouse (Expt. 2). Seeds of 10 bedding species and cultivars, provided by Ball Horticultural Company (Chicago, IL; Table 1), were sown in 72-cell trays filled with a germination mix (Sunshine Mix No. 5; SunGro Hort., Bellevue, WA) in a mist bench with reverse osmosis (RO) water in the greenhouse. For Expt. 2, eight bedding plants were used, excluding Angelonia angustifolia 'White' and 'Lavender Pink' (Table 1). After germination, seedlings were grown in $500-\mathrm{mL}$ pots (one plant per pot) filled with similar potting mix with additional coarse perlite to improve drainage (Sunshine Mix No. 4; SunGro Hort.) in the greenhouse. Seedlings were transplanted on 23 May 2008 (Expt. 1) or 19 Nov. 2008 (Expt. 2) to 2.6-L pots for angelonia (three cultivars), licorice plant, and plumbago or to 10-L pots for the other species. Controlled-release fertilizer $14 \mathrm{~N}-6 \mathrm{P}-12 \mathrm{~K}$ (Osmocote 14-14-14; Scotts-Sierra Hort. Products, Marysville, $\mathrm{OH})$ was top-dressed at $5.0 \mathrm{~g} \cdot \mathrm{L}^{-1}$ (13 g and $48 \mathrm{~g}$ for $2.6-\mathrm{L}$ and 10-L containers, respectively) and Micromax (Scotts-Sierra Hort. Products) at $0.5 \mathrm{~g} \cdot \mathrm{L}^{-1}(2 \mathrm{~g}$ and $6 \mathrm{~g}$ for 2.6-L and 10-L containers, respectively). For Expt. 1, plants were moved to the shadehouse 1 week after transplanting. The outdoor environmental conditions for Expt. 1 were recorded by an on-site weather station nearby (Fig. 1). The average air temperatures in the greenhouse for Expt. 2 were maintained at $23 \pm 2{ }^{\circ} \mathrm{C}$ during the day and $20 \pm 2{ }^{\circ} \mathrm{C}$ at night and the daily light integral (photosynthetically active radiation) ranged from 7 to $11 \mathrm{~mol} \cdot \mathrm{m}^{-2} \cdot \mathrm{d}^{-1}$. A $21 \mathrm{X}$ datalogger (Campbell Scientific, Logan, UT) was used to measure temperature and light every $10 \mathrm{~s}$ and record the hourly and daily average.

Experimental design and treatment. Both experiments were a split-plot design with the salinity of the irrigation water as the main plot and species and cultivars as subplots with six replications. Saline solutions at five salinity levels were prepared by adding appropriate amounts of sodium chloride $(\mathrm{NaCl})$, magnesium sulfate $\left(\mathrm{MgSO}_{4} \cdot 7 \mathrm{H}_{2} \mathrm{O}\right)$, and calcium chloride $\left(\mathrm{CaCl}_{2}\right)$ at 87:8:5 (by weight) to tap water, creating an electrical conductivity (EC) of 0.8 (tap water, control), 2.8, 4.0, 5.1, or 7.4 $\mathrm{dS} \cdot \mathrm{m}^{-1}$. The EC of reclaimed water, which varies with source water and treatment method, ranges from 1.0 to $1.9 \mathrm{dS} \cdot \mathrm{m}^{-1}$ (Schuch, 2005; Wu et al., 2001). These EC levels were chosen based on the assumption that salt tolerance of the selected bedding plants differs and their EC thresholds, which lead to significant growth reduction, are within the range. The major ions in the tap water were sodium $(\mathrm{Na})$, calcium, magnesium, $\mathrm{Cl}$, and $\mathrm{SO}_{4}$ at 184, 52.0, 7.5, 223.6, and $105.6 \mathrm{mg} \cdot \mathrm{L}^{-1}$, respectively. The composition of the saline solutions was similar to that of the local municipal reclaimed water. Saline solutions were prepared in 100-L tanks with confirmed EC for each treatment. Saline water irrigation was initiated on 5 June and ended on 5 Sept. 2008 for Expt. 1 in the shadehouse and from 19 Dec. to 10 Feb. 2009 for Expt. 2 in the greenhouse. The reason for ending Expt. 2 earlier was because salt accumulated rapidly in the root zone and approx-

Table 1. A list of plant species and cultivars used in the two experiments.

\begin{tabular}{lll}
\hline Botanical name & Common name & Cultivar \\
\hline Angelonia angustifolia & Angelonia & Lavender Pink $^{z}$ \\
A. angustifolia & Angelonia & Purple \\
A. angustifolia & Angelonia & White $^{z}$ \\
Capsicum annuum & Ornamental pepper & Black Pearl \\
C. annuum & Ornamental pepper & Calico \\
C. annuum & Ornamental pepper & Purple Flash \\
Catharanthus roseus & Vinca & Rose \\
Helenium amarum & Helenium & Dakota Gold \\
Helichrysum petiolatum & Licorice plant & Silver Mist \\
Plumbago auriculata & Plumbago & Escapade Blue \\
\hline
\end{tabular}

${ }^{\mathrm{z}}$ Expt. 1 only.
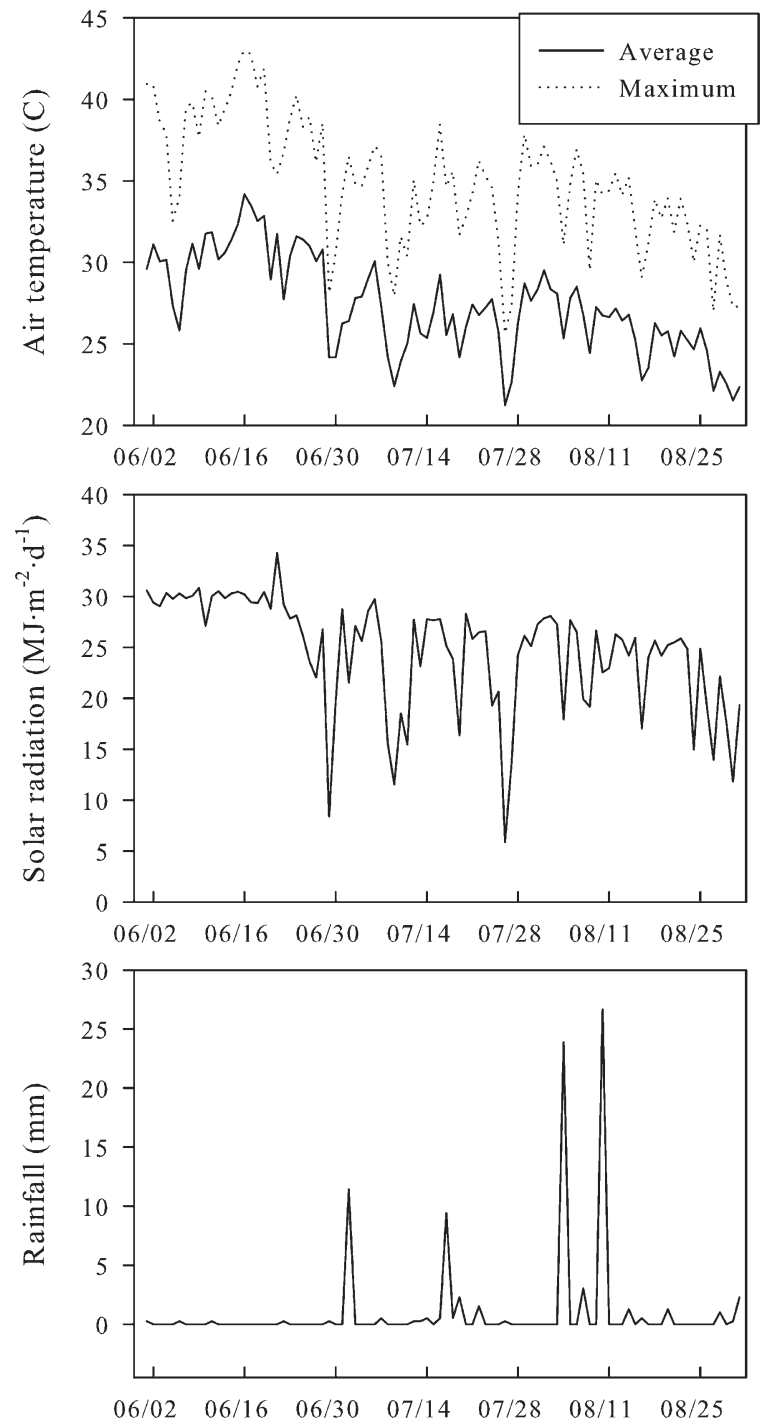

Day of year

Fig. 1. Air temperatures, solar radiation, and rainfall during the experimental period (Expt. 1), 1 June to 5 Sept. 2008, El Paso, TX.

imately half of plumbago plants elongated to over $110 \mathrm{~cm}$. Plants were irrigated manually with $1 \mathrm{~L}$ or $2 \mathrm{~L}$ solutions per pot for 2.6-L or $10-\mathrm{L}$ pots, respectively. Irrigation intervals were determined according to plant species, treatment, and weather conditions to prevent water stress.

Measurement. Plant height and two perpendicular canopy widths were recorded monthly to calculate the growth index: [height $+($ width $1+$ width 2$) / 2] / 2$. On termination of the experiment, shoot dry weight (DW) was determined after oven-drying at $70{ }^{\circ} \mathrm{C}$ to constant weight. To monitor salt accumulation in the root zone, a WET sensor (Delta-T Devices, Cambridge, U.K.) was used to measure the salinity level in the root zone before and after the irrigation for Expt. 1 
periodically. Using the WET sensor to monitor salinity was relatively quick and easy. However, the readings at salinities higher than $3.0 \mathrm{dS} \cdot \mathrm{m}^{-1}$ were not accurate (Scoggins and van Iersel, 2006). Therefore, for Expt. 2, leachate was collected on four pots per treatment $31 \mathrm{~d}$ after the treatments and at the end of the experiments. The $\mathrm{EC}$ and $\mathrm{pH}$ of leachate were determined using a salinity and pH meter (Model B-173; Horiba, Ltd., Kyoto, Japan). The solution was diluted properly whenever the leachate EC exceeded 20 $\mathrm{dS} \cdot \mathrm{m}^{-1}$ by adding deionized water to obtain the actual EC accurately. Because EC for some species at high salinity treatments (5.1 and $7.4 \mathrm{dS} \cdot \mathrm{m}^{-1}$ ) were too high (greater than 20 $\left.\mathrm{dS} \cdot \mathrm{m}^{-1}\right)$, all containers were flushed with RO water $\left(\mathrm{EC} \approx 0 \mathrm{dS} \cdot \mathrm{m}^{-1}\right)$ for multiple times until the EC of leachate was similar to or lower than those of the irrigation solutions.

Leaf osmotic potential $\left(\psi_{\mathrm{s}}\right)$ was determined as described in Niu and Rodriguez (2006a) and Niu et al. (2008). Specifically, leaves were sampled from the middle section of the shoots in the early morning at the end of the experiment (Expt. 1), washed in deionized water and dried by a paper towel, sealed in a plastic bag, and immediately stored in a freezer at $-20{ }^{\circ} \mathrm{C}$ until analysis. Frozen leaves were thawed in a plastic bag at room temperature before sap was pressed out with a Markhart leaf press (LP-27; Wescor, Logan, UT) and analyzed using a vapor pressure osmometer (Vapro Model 5520; Wescor).

To analyze $\mathrm{Na}$ and $\mathrm{Cl}$ concentrations, three leaf samples per treatment were randomly collected at the end of Expt. 1, washed three times with deionized water, and ovendried at $70{ }^{\circ} \mathrm{C}$. Dried leaves were ground to pass a 40-mesh screen with a stainless Wiley mill and the samples were submitted to the Soil, Water, and Air Testing Laboratory of New Mexico State University (Las Cruces, $\mathrm{NM}$ ) for $\mathrm{Na}$ and $\mathrm{Cl}$ analyses. Na concentrations were determined by EPA method 200.7 [U.S. Environmental Protection Agency (EPA), 1983)] and analyzed using an Inductively Coupled Plasma/Atomic Emission Spectrophotometer Trace Analyzer (Thermo Jarrell Ash, Franklin, MA). Cl was determined by EPA method 300.0 (U.S. EPA, 1983) and analyzed using an ion chromatograph (Dionex, Sunnyvale, CA).

Statistical analysis. All data were analyzed by a two-way analysis of variance using PROC GLM. When the main effect was significant, linear or quadratic regression was performed using PROC REG. The differences of the two lines were analyzed using the GLM procedure by comparing the slopes and intercepts. To determine the threshold salinity level on plant growth, Student-Newman-Keuls multiple comparisons were performed. All statistical analyses were performed using SAS software (SAS Institute, 2002).

\section{Results and Discussion}

Expt. 1

All plants survived, regardless of treatment, except for ornamental pepper 'Purple
Flash'. The mortality of ornamental pepper 'Purple Flash' was $17 \%, 17 \%, 33 \%, 50 \%$, and $100 \%$, when plants were irrigated with saline solutions at EC of 0.8, 2.8, 4.0, 5.1, and $7.4 \mathrm{dS} \cdot \mathrm{m}^{-1}$, respectively. Because mortality occurred at the beginning of the study, transplanting shock and salinity stress may both have contributed to plant death. No visual foliar damage was observed in any other species regardless of treatment in Expt. 1. Because the root zone salinity measured by the WET sensor on 19 June was unaffected by species, all subsequent measurements were carried out on selected species and the data were pooled. As shown in Figure 2, root zone salinity did not fluctuate from late June to late July but decreased after late July, which may be the result of several significant rainfalls during that period (Fig. 1). Salt accumulation in the root zone was observed in our previous greenhouse studies when similar potting media were used (Niu and Rodriguez, 2006a, 2006b). The salinity range for the WET sensor was below $3.0 \mathrm{dS} \cdot \mathrm{m}^{-1}$; above this range, readings are less accurate (Scoggins and van Iersel, 2006). Therefore, the absolute salinity levels measured by this sensor may be used as a reference at salinity levels higher than $3.0 \mathrm{dS} \cdot \mathrm{m}^{-1}$. Nevertheless, the changing of the readings over time is useful regarding whether salt was accumulated in the root zone.

Growth. Shoot DW of angelonia 'White' and 'Lavender Pink' decreased linearly, whereas that of angelonia 'Purple' decreased in a quadratic fashion as the EC of irrigation water increased (Fig. 3). Generally, there were no differences in shoot DW of angelonia cultivars at EC of $0.8,2.8$, and $4.0 \mathrm{dS} \cdot \mathrm{m}^{-1}$. Shoot DW of the three angelonia cultivars at EC of $5.1 \mathrm{dS} \cdot \mathrm{m}^{-1}$ and $7.4 \mathrm{dS} \cdot \mathrm{m}^{-1}$ decreased by $25 \%$ and $50 \%$, respectively, compared with those at EC of $2.8 \mathrm{dS} \cdot \mathrm{m}^{-1}$. Shoot DW of ornamental pepper 'Black Pearl' and 'Calico' decreased linearly as $\mathrm{EC}$ of irrigation water increased and the magnitude of growth reduction was larger in 'Black Pearl' than in 'Calico'. For example, per unit increase in EC, shoot DW decreased by $11.69 \mathrm{~g}$ and $6.49 \mathrm{~g}$ in 'Black Pearl' and 'Calico' ( $P=0.008$, slope comparison), respectively. No differences in shoot DW of the survived ornamental pepper 'Purple Flash' were found among the four treatments. For vinca and helenium, shoot DW decreased linearly as EC of irrigation water increased. The shoot DW of licorice plant at $7.4 \mathrm{dS} \cdot \mathrm{m}^{-1}$ was lower than those in other treatments except for $5.0 \mathrm{dS} \cdot \mathrm{m}^{-1}$ and shoot DW of plumbago at EC of $7.4 \mathrm{dS} \cdot \mathrm{m}^{-1}$ was lower than those at EC of $0.8 \mathrm{dS} \cdot \mathrm{m}^{-1}$ and $2.8 \mathrm{dS} \cdot \mathrm{m}^{-1}(P=0.05)$. Based on linear regression in shoot DW versus EC of irrigation water, shoot DW of ornamental pepper 'Black Pearl' decreased more rapidly followed by ornamental pepper 'Calico' and vinca, helenium, and the remaining three: angelonia 'White', 'Lavender Pink', and plumbago.

The final growth index of angelonia 'White' was unaffected by the treatment (Fig. 4). For angelonia 'Purple' and 'Lavender Pink', growth index was generally larger at EC of $2.8 \mathrm{dS} \cdot \mathrm{m}^{-1}$ and $4.0 \mathrm{dS} \cdot \mathrm{m}^{-1}$ compared with other treatments $(P=0.05)$. In ornamental peppers, growth index of 'Black Pearl' decreased linearly as EC of irrigation water increased, whereas those of 'Calico' and 'Purple Flash' were unaffected. Growth index of helenium and vinca also decreased linearly as salinity of irrigation water increased. Salinity treatment did not affect the growth index of licorice plant and plumbago. For the linear regressions between growth index and salinity of irrigation water, ornamental pepper 'Black Pearl' had a steeper slope followed by vinca and helenium

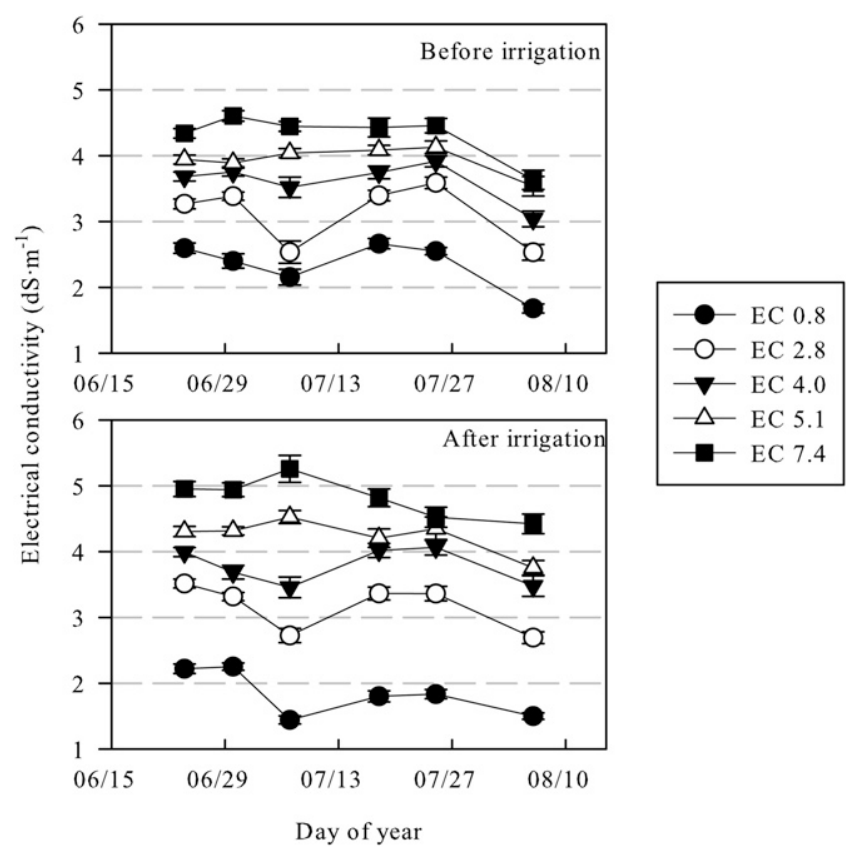

Fig. 2. Electrical conductivityin the root zone measured by a WET sensor before and after irrigation. Data were pooled from all species. Vertical bars represent SEs (Expt. 1). 

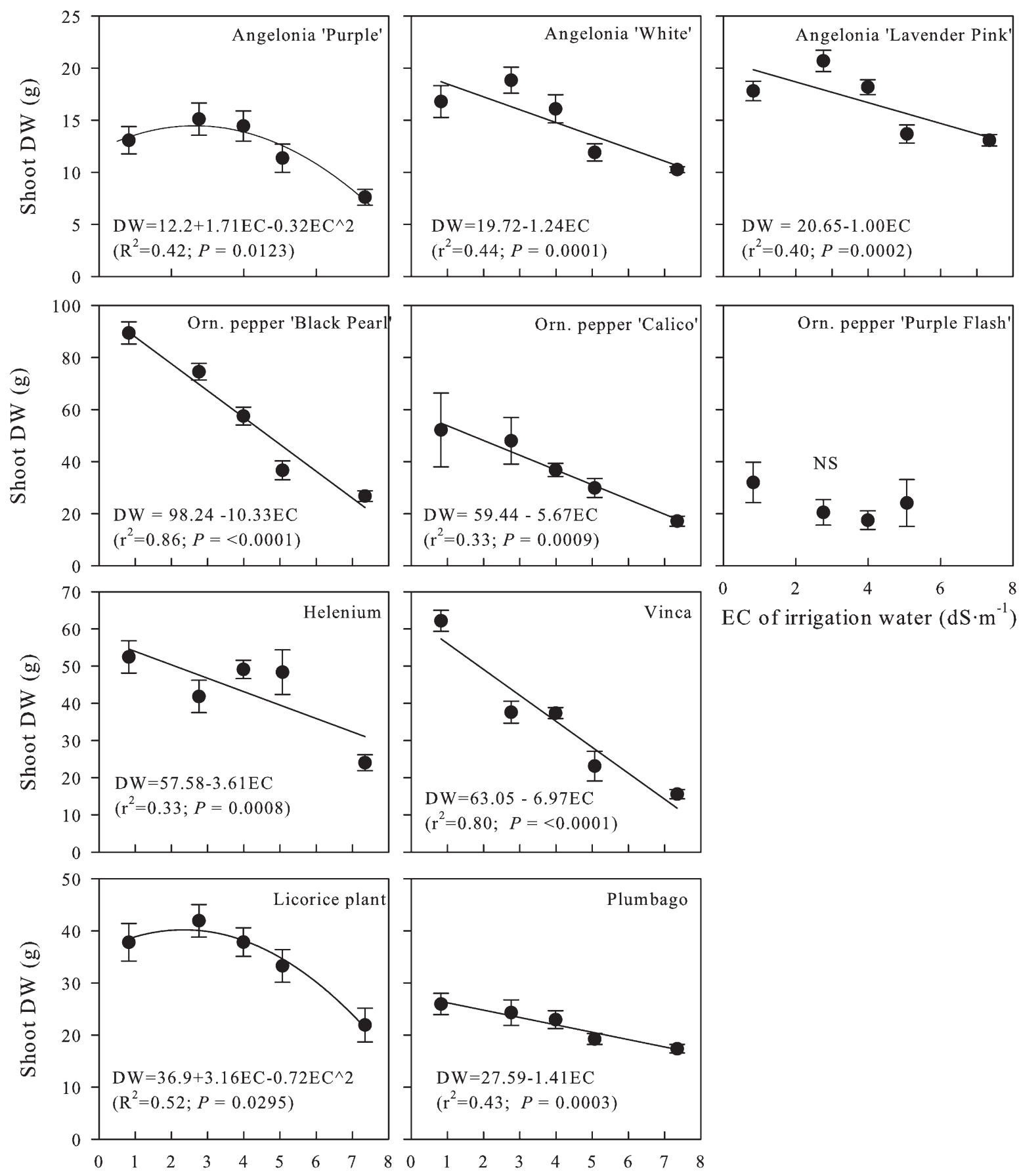

EC of irrigation water $\left(\mathrm{dS} \cdot \mathrm{m}^{-1}\right)$ EC of irrigation water $\left(\mathrm{dS} \cdot \mathrm{m}^{-1}\right)$

Fig. 3. Shoot dry weight (DW) of 10 bedding plants irrigated with water at electrical conductivity (EC) of $0.8,2.8,4.0,5.1$, or $7.4 \mathrm{dS} \cdot \mathrm{m}^{-1}$ (Expt. 1). Vertical bars represent SES. NS indicates nonsignificance. Means with same letters indicate not significantly different tested by Student-Newman-Keuls at $P=0.05$.

and angelonia 'Lavender Pink'. Therefore, ornamental pepper 'Black Pearl' was the most sensitive to salinity stress among the 10 species and cultivars based on its shoot DW and growth index.

Osmotic potential. Salinity of the irrigation water and species had an interactive effect on $\psi_{\mathrm{s}}$, indicating that salinity effect on $\psi_{\mathrm{s}}$ varied with species.

Osmotic potentials of angelonia 'Purple', ornamental pepper 'Black Pearl' and 'Calico', helenium, vinca, and licorice plants decreased linearly as salinity of irrigation water increased (Fig. 5). In angelonia 'Lavender Pink' and ornamental pepper 'Purple Flash', salinity treatment did not affect leaf $\psi_{\mathrm{s}}$. In angelonia 'White' and plumbago, $\psi_{\mathrm{s}}$ followed a quadratic fashion as salinity of irrigation water increased. The lowest $\psi_{\mathrm{s}}$ was found in licorice plants at EC of $7.4 \mathrm{dS} \cdot \mathrm{m}^{-1}$. Also, in the licorice plant, the relationship between $\psi_{\mathrm{s}}$ and salinity of irrigation water was different from those in other species. For example, compared with helenium, the licorice plant had a steeper slope $(P=0.001)$ and a lower intercept $(P=0.0009)$. In ornamental pepper, 'Black Pearl' had a lower intercept $(P=0.0121)$ compared with 'Calico', indicating a lower $\psi_{\mathrm{s}}$ in the control treatment in 'Black Pearl' than in 'Calico'. In vinca, $\psi_{\mathrm{s}}$ decreased more slowly compared with helenium and 'Black Pearl' $(P<0.0001$ and $P=0.0071$, respectively).

Tissue sodium and chlorine analysis. There were interactive effects of salinity of the irrigation water and species on tissue $\mathrm{Na}$ and $\mathrm{Cl}$ concentrations, indicating that the salinity effect on $\mathrm{Na}$ and $\mathrm{Cl}$ uptake varied with species. In all species, leaf $\mathrm{Na}$ and $\mathrm{Cl}$ 

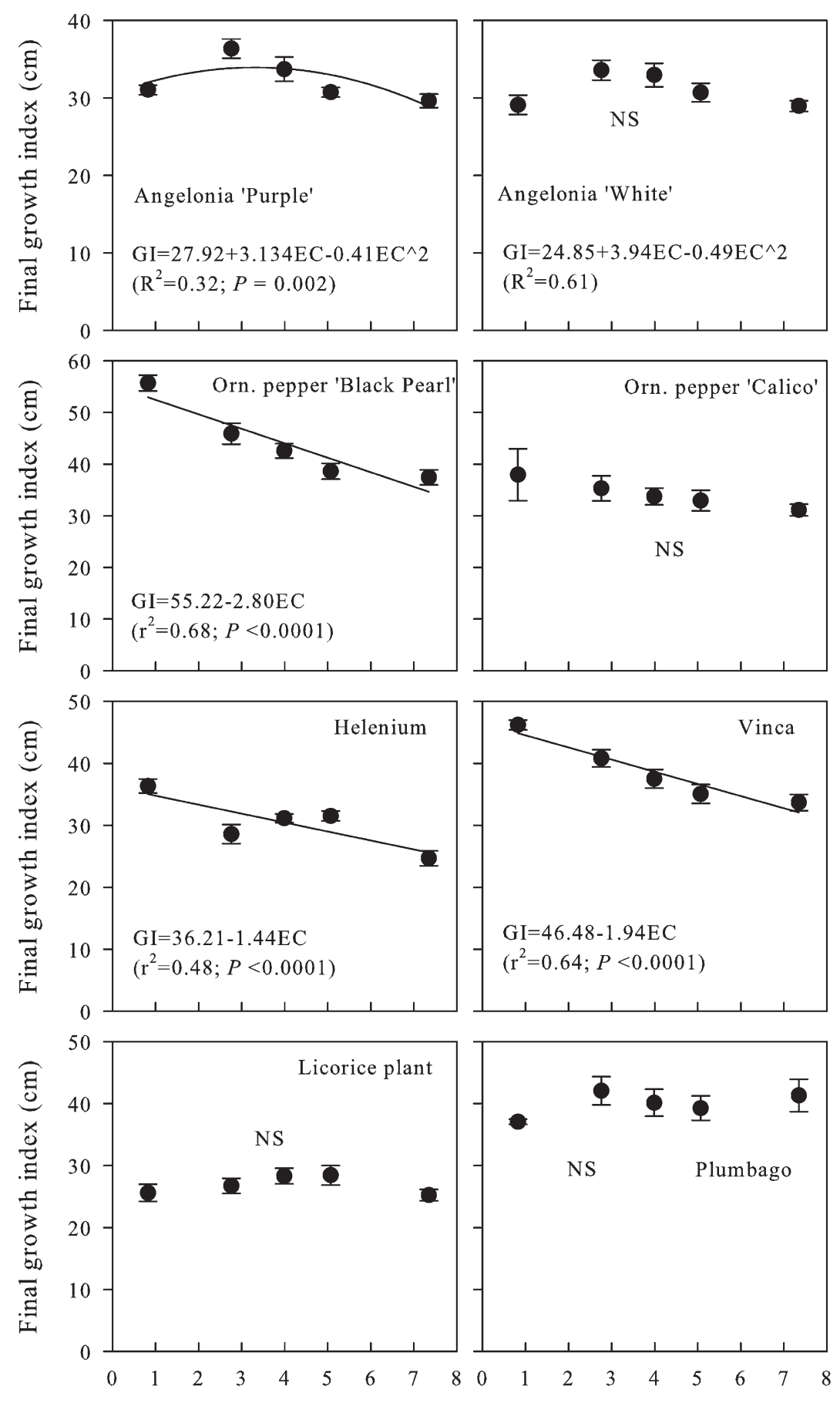

\section{EC of irrigation water $\left(\mathrm{dS} \cdot \mathrm{m}^{-1}\right)$ EC of irrigation water $\left(\mathrm{dS} \cdot \mathrm{m}^{-1}\right)$}
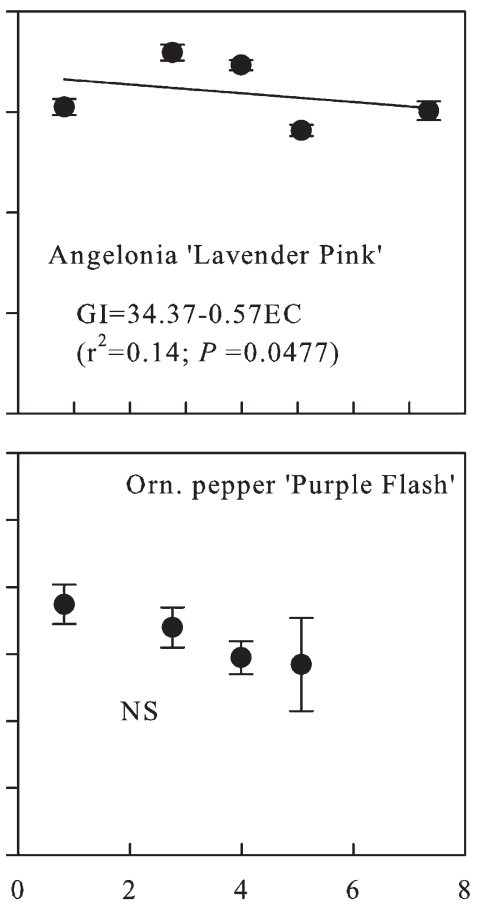

EC of irrigation water $\left(\mathrm{dS} \cdot \mathrm{m}^{-1}\right)$

Fig. 4. Growth index (GI) of 10 bedding plants irrigated with water at electrical conductivity (EC) of $0.8,2.8,4.0,5.1$, or 7.4 dS.m ${ }^{-1}$ (Expt. 1). Vertical bars represent SES. NS indicates nonsignificance. Means with same letters indicate not significantly different tested by Student-Newman-Keuls at $P=0.05$.

increased linearly as salinity of irrigation water increased (Fig. 6). Among the three angelonia cultivars, leaf $\mathrm{Na}$ concentration in 'Purple' had a steeper increase compared with 'Lavender Pink' $(P=0.0105)$ and 'White' $(P=0.0287)$. 'Lavender Pink' and 'White' had similar linear relationships in $\mathrm{Na}$ versus salinity. For $\mathrm{Cl}$ versus salinity, no differences were found between 'Lavender Pink' and 'Purple' and between 'Lavender Pink' and 'White', whereas the $\mathrm{Cl}$ concentration in 'Purple' increased with salinity of irrigation water more rapidly compared with 'White'
$(P=0.0202)$. In ornamental peppers, both $\mathrm{Na}$ and $\mathrm{Cl}$ concentrations in 'Black Pearl' increased more rapidly with salinity of irrigation water compared with 'Calico'. However, no differences were found in $\mathrm{Na}$ versus salinity and $\mathrm{Cl}$ versus salinity regressions between 'Black Pearl' and 'Purple Flash' or between 'Calico' and 'Purple Flash'. Among the three cultivars, 'Black Pearl' had the highest $\mathrm{Na}$ and $\mathrm{Cl}$ concentrations, which contributed to greater reduction in shoot growth. Helenium and vinca had similar regressions in $\mathrm{Na}$ and $\mathrm{Cl}$ versus salinity of irrigation water and the same for licorice plant and plumbago in which changes in $\mathrm{Na}$ and $\mathrm{Cl}$ concentrations followed similar patterns (both intercept and slope) as salinity of irrigation water increased. Except for 'Black Pearl' in which leaf $\mathrm{Cl}$ concentration was $57 \mathrm{~g} \cdot \mathrm{kg}^{-1}$, the highest $\mathrm{Cl}$ concentrations in other species were $\approx 30 \mathrm{~g} \cdot \mathrm{kg}^{-1}$ or lower.

\section{Expt. 2}

Salinity treatment and species interactively affected leachate EC and pH (Fig. 7), indicating that salt accumulation varied with species and treatment. On Day 31, plumbago 

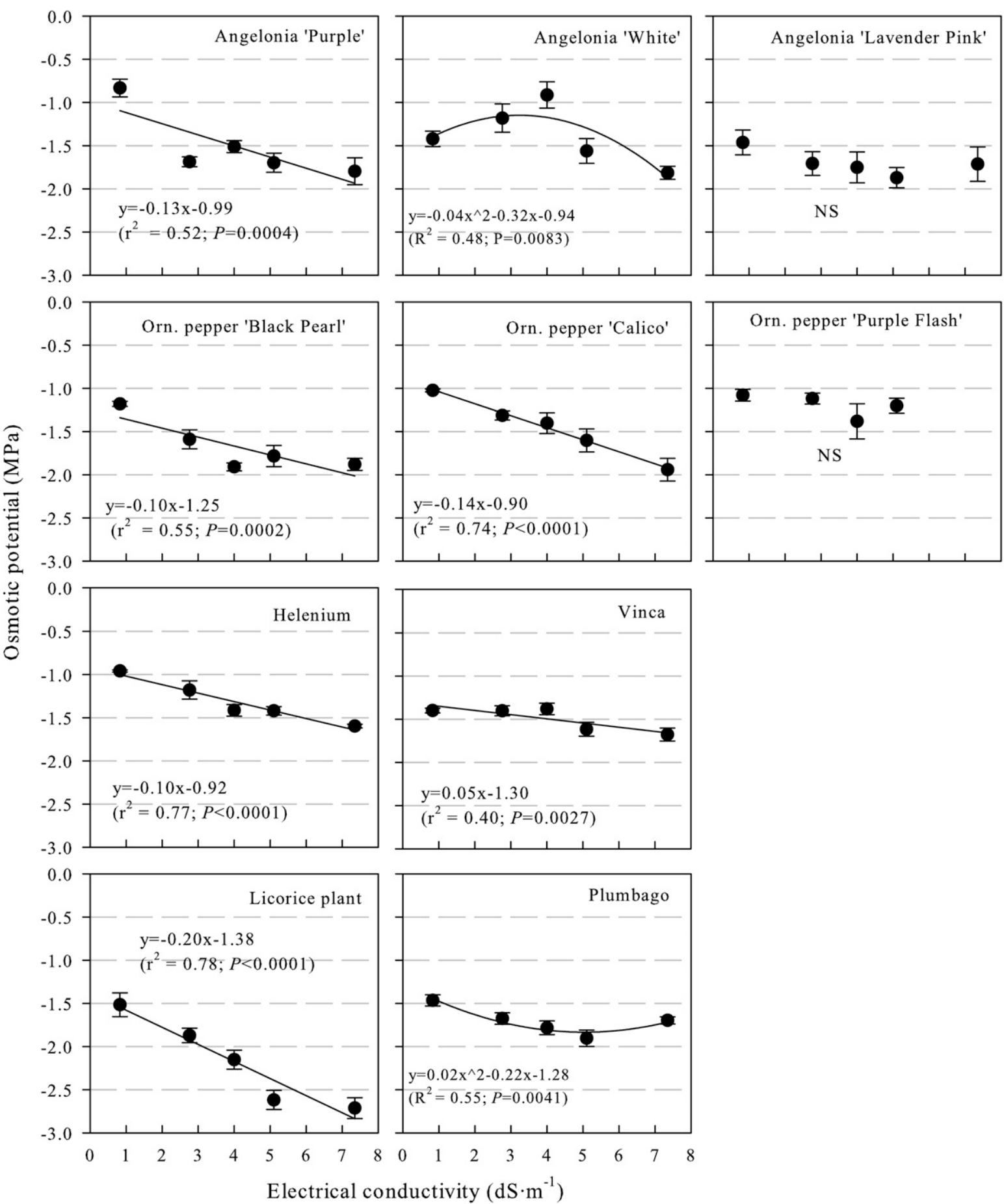

Fig. 5. Leaf osmotic potential of 10 bedding plants irrigated with water at electrical conductivity (EC) of $0.8,2.8,4.0,5.1$, or $7.4 \mathrm{dS} \cdot \mathrm{m}^{-1}$ (Expt. 1). Vertical bars represent SES. NS indicates nonsignificance.

and angelonia had the highest leachate EC (over $30 \mathrm{dS} \cdot \mathrm{m}^{-1}$ ) in the $7.4 \mathrm{dS} \cdot \mathrm{m}^{-1}$ treatment, whereas leachate EC of other species in the highest salinity treatment was $\approx 20 \mathrm{dS} \cdot \mathrm{m}^{-1}$. For helenium and vinca, leachate EC in the control was over $10 \mathrm{dS} \cdot \mathrm{m}^{-1}$, higher than those in most other species; thus, the difference between the control and the highest salinity treatments was small, $\approx 7 \mathrm{dS} \cdot \mathrm{m}^{-1}$. At the end of the experiment (Day 52), 2 weeks after all containers were flushed with RO water on Day 38, leachate EC of all treatments for all species decreased. Apparently, the high saline root zone did not last long enough to cause severe damage or death on these species and cultivars. On the other hand, these species and cultivars could tolerate high root zone salinity for a short period of time.

Leachate $\mathrm{pH}$ was also affected by species and salinity treatments (Fig. 7). On Days 31 and 52, the licorice plant had the highest leachate $\mathrm{pH}$, between 6.0 and 6.9 (normal range) for all treatments except for the 4.0 $\mathrm{dS} \cdot \mathrm{m}^{-1}$ treatment. On Day 52, plumbago and angelonia also had a leachate $\mathrm{pH}$ range of 6.0 to 7.0 except for the $7.4 \mathrm{dS} \cdot \mathrm{m}^{-1}$ treatment.
Generally, as salt accumulated in the root zone, leachate $\mathrm{pH}$ for ornamental peppers, vinca, and helenium was low on both days compared with the other species.

All plants survived in Expt. 2 regardless of species and treatment. Saline water irrigation was initiated 3 weeks after transplanting. After transplanting and before the initiation of the treatment, several ornamental peppers, mostly 'Purple Flash', died, which confirmed our hypothesis in Expt. 1 that both salinity stress and transplanting shock contributed to plant death. Foliar injuries (discoloring and 

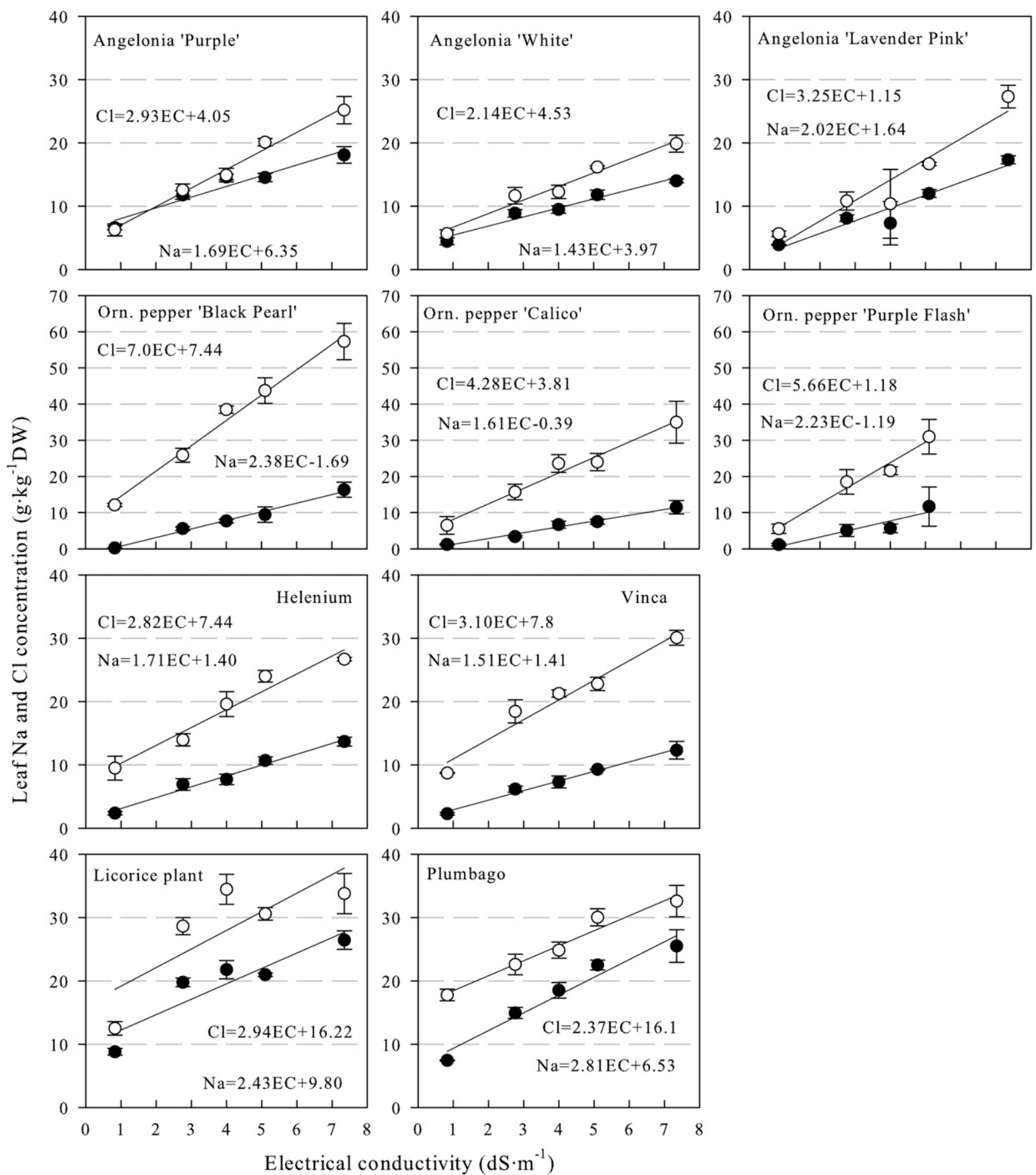

Fig. 6. Shoot sodium (solid circle) and chlorine (open circle) concentrations of 10 bedding plants irrigated with water at electrical conductivity (EC) of $0.8,2.8$, 4.0, 5.1, or $7.4 \mathrm{dS} \cdot \mathrm{m}^{-1}$ (Expt. 1). Vertical bars represent SES. NS indicates nonsignificance.

necrosis) in the three ornamental pepper cultivars were observed on some plants at 7.4 $\mathrm{dS} \cdot \mathrm{m}^{-1}$ during the late part of the experiment. Generally, this foliar injury was not severe; less than half of the plants at $7.4 \mathrm{dS} \cdot \mathrm{m}^{-1}$ exhibited foliar injury on less than $10 \%$ leaves.

Shoot DW in plumbago, angelonia 'Purple' (the other two angelonia cultivars were not repeated), and ornamental pepper 'Black Pearl' decreased as salinity of irrigation water increased (Fig. 8). Shoot DW of other species was unaffected by the salinity treatment (data not shown). Rapid salt accumulation may have in part diminished the differences in growth among treatments in these species. For example, the largest differences in leachate $\mathrm{EC}$ on
Day 31 for vinca and helenium among treatments were $\approx 7.0 \mathrm{dS} \cdot \mathrm{m}^{-1}$ or smaller, which were much smaller compared with those for ornamental pepper 'Black Pearl', plumbago, and angelonia. Shoot DW reduction by the elevated salinity was highest in 'Black Pearl' followed by plumbago and angelonia 'Purple' in which leachate EC was highest on Day 31.

Salinity treatment affected growth index in ornamental pepper 'Black Pearl' and helenium but not in other species (data not shown). The average height of plumbago in Expt. 2, which was unaffected by the treatment, was $110 \mathrm{~cm}$, more than double the height of the plants in Expt. 1 (data not shown). Plumbago plants became less branched as salinity in- creased, which resulted in a low shoot DW. The high humidity and low light in the greenhouse probably favored the shoot elongation for plumbago.

Environmental conditions modify plant response to salinity stress (Fox et al., 2005; Niu et al., 2007; Zollinger et al., 2007). The light intensity and temperatures were much lower in Expt. 2 than those in Expt. 1, which may contribute to the different responses of some species such as vinca in Expt. 2 compared with Expt. 1. As a result of the lower temperature, light intensity, and high humidity, less frequent irrigation was needed in Expt. 2. However, root zone salinity in Expt. 2, measured by leachate EC on Day 31, was 

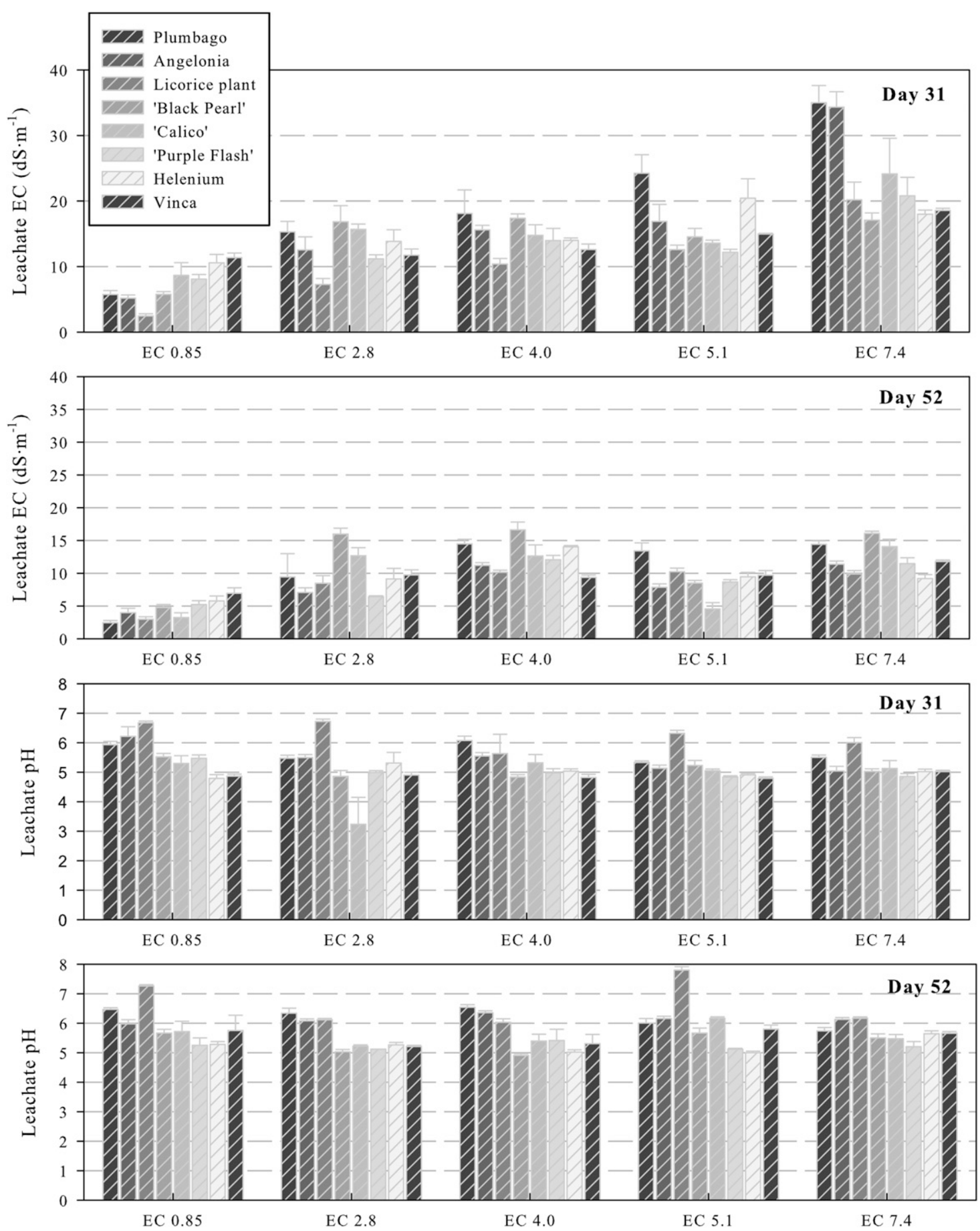

Fig. 7. Leachate electrical conductivity (EC) and $\mathrm{pH}$ measured on Day 31 and Day 52 (at the end of the experiment) of eight bedding plants irrigated with water at EC of $0.8,2.8,4.0,5.1$, or $7.4 \mathrm{dS} \cdot \mathrm{m}^{-1}$ (Expt. 2). Vertical bars represent SES.

two to seven times higher than that of the irrigation solutions depending on species and treatment. In other words, root zone salinity levels can increase by several times in 1 month. Increasing leaching fraction is necessary to avoid rapid salt accumulation. Leaching fraction measured on Day 31, which varied with species and treatment, was $22 \%$ on average. Using porous substrate is another option to prevent root zone salinity from rising to hazardous levels.

Salt tolerance assessment for landscape plants should be based primarily on their aesthetical appearance instead of maximizing growth (Cameron et al., 2004; Fox et al., 2005), especially for rapidly growing plant species. For example, although a significant reduction of growth in ornamental peppers 'Black Pearl' and 'Calico' was observed under elevated salinity conditions compared with the plants irrigated with tap water in Expt. 1, their compact appearance was more desirable and required less maintenance. Based on this criterion, all species and cultivars tested in this study can be irrigated with saline water at EC of $4.0 \mathrm{dS} \cdot \mathrm{m}^{-1}$ or lower if these plants are used in a landscape with equivalent rainfall as shown in Figure 1.
'Black Pearl' may suffer a significant growth reduction but no visual salt injury. Root zone salinity level needs to be monitored and considered when determining salinity threshold of irrigation water. For soils or substrates with adequate drainage, salinity of leachate may be close to that of irrigation water. However, if heavy soil is used, low-quality water should be avoided as a result of potential excessive salt accumulation. The average EC of municipal reclaimed water is usually less than $2.0 \mathrm{dS} \cdot \mathrm{m}^{-1}$ depending on region or water source (Khurram and Miyamoto, 2005; Wu et al., 2001). As shown in Figure 7, salts 


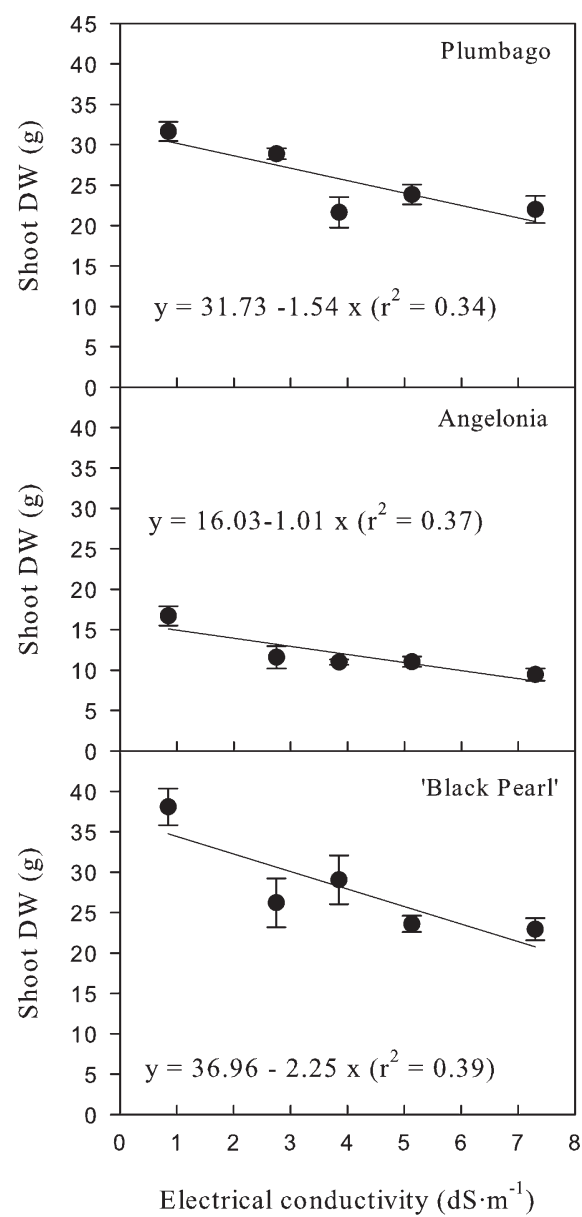

Fig. 8. Shoot dry weight (DW) of angelonia (Angelonia angustifolia) 'Purple', ornamental pepper (Capsicum annuum) 'Black Pearl', and plumbago (Plumbago auriculata) irrigated with water at electrical conductivity (EC) of $0.8,2.8,4.0$, 5.1 , or $7.4 \mathrm{dS} \cdot \mathrm{m}^{-1}$ (Expt. 2). Vertical bars represent SES. L and Q in legend parentheses indicate linear and quadratic regression. $*, * *, * * *$, NS indicates significant and nonsignificant at $P=$ $0.05,0.01$, or 0.001 , respectively.

could accumulate significantly in 1 month even in the control with an EC of $0.85 \mathrm{dS} \cdot \mathrm{m}^{-1}$. As salinity increased, $\mathrm{pH}$ is changed accordingly, depending on species. A low (below 5.0) or high $\mathrm{pH}$ (greater than 6.9) in the media may affect micronutrient uptake causing nutrient imbalances (Reed, 1996).

Some species tolerate salt stress by avoiding uptake of certain ions or by tolerating high ion concentrations in the tissue. The sensitivity or tolerance to high internal $\mathrm{Na}$ or $\mathrm{Cl}$ levels varies among species. For example, Delosperma cooperi irrigated with saline solution at $6.4 \mathrm{dS} \cdot \mathrm{m}^{-1}$ had a low $\left(8.5 \mathrm{mg} \cdot \mathrm{g}^{-1}\right)$ $\mathrm{Na}$ concentration in shoots by limiting the transportation of $\mathrm{Na}$ from roots to shoots, whereas the $\mathrm{Cl}$ concentration in shoots was as high as $97 \mathrm{mg} \cdot \mathrm{g}^{-1}$ with no visual injury and no growth reduction compared with the control (Niu and Rodriguez, 2006a). In rose rootstocks irrigated with saline solution at 8.0 $\mathrm{dS} \cdot \mathrm{m}^{-1}$ (Niu and Rodriguez, 2008), the shoot $\mathrm{Na}$ and $\mathrm{Cl}$ concentrations were much lower, with severe visual injuries, than those found in the bedding plants in the current study. Therefore, the bedding plants tested in this study have high tolerance to high internal $\mathrm{Na}$ and $\mathrm{Cl}$ concentrations. Among the 10 bedding plants, licorice plants and plumbago had higher Na uptake in shoots with smaller growth reduction compared with vinca and ornamental pepper 'Black Pearl', indicating that licorice plants and plumbago tolerate higher internal $\mathrm{Na}$ concentrations. Because bedding plants are generally replaced every year in landscapes, the excessive accumulation of ions may not pose a hazard as long as no visual injuries are exhibited throughout the current growing season.

In summary, the salt tolerance of the 10 bedding plants varied with species and cultivars. Ornamental pepper 'Black Pearl' was most sensitive to salt stress based on its greater growth reduction in both experiments and high accumulation of $\mathrm{Cl}$ in leaves compared with other plants. Niu et al. (2007) concluded that salt tolerance of several herbaceous plants obtained from greenhouse studies using soilless potting media were consistent with those from the field study. Although not tested under a saline field condition, all species and cultivars may be irrigated with saline water at salinity of $4.0 \mathrm{dS} \cdot \mathrm{m}^{-1}$ or lower provided that well-drained soils or substrates are used to prevent excessive salt accumulation in the root zone. It is possible that plant response to salinity stress may be modified by soil type in a landscape situation.

\section{Literature Cited}

Cabrera, R.I. and P. Perdomo. 2003. Reassessing the salinity tolerance of greenhouse roses under soilless production conditions. HortScience 38 : 533-536.

Cameron, R.W.F., S. Wilkinson, W.J. Davies, R.S Harrison-Murray, D. Dunstan, and C. Burgess. 2004. Regulation of plant growth in containergrown ornamentals through the use of controlled irrigation. Acta Hort. 630:305-312.

Carter, C.T. and C.M. Grieve. 2006. Salt tolerance of floricultural crops, p. 279-287. In: Khan, M.A. and D.J. Weber (eds.). Ecophysiology of high salinity tolerant plants. Springer, Dordrecht, The Netherlands.

Dobrowolski, J., M. O'Neill, L. Duriancik, and J. Throwe. 2008. Opportunities and challenges in agricultural water reuse: Final report. USDACSREES.
Fox, L.J., J.N. Grose, B.L. Appleton, and S.J. Donohue. 2005. Evaluation of treated effluent as an irrigation source for landscape plants. J. Environ. Hort. 23:174-178.

Gerhart, V.J., R. Kane, and E.P. Glenn. 2006. Recycling industrial saline wastewater for landscape irrigation in a desert urban area J. Arid Environ. 67:473-486.

Grieve, C.M., J.A. Poss, and C. Amrhein. 2006. Response of Matthiola incana to irrigation with saline wastewaters. HortScience 41:119-123.

Khurram, S. and S. Miyamoto. 2005. Seedling growth, leaf injury and ion uptake response of cold-resistant palm species to salinity. J. Environ. Hort. 23:193-198.

Kjelgren, R., L. Rupp, and D. Kilgren. 2000. Water conservation in urban landscapes. HortScience 35:1037-1040.

Miyamoto, S., A. Chacon, M. Hossain, and I. Martinez. 2005. Soil salinity of urban turf areas irrigated with saline water. I. Spatial variability. Landsc. Urban Plan. 71:233-241.

Niu, G. and D.S. Rodriguez. 2006a. Relative salt tolerance of five herbaceous perennials. HortScience 41:1493-1497.

Niu, G. and D.S. Rodriguez. 2006b. Relative salt tolerance of selected herbaceous perennials and groundcovers. Scientia Hort. 110:352-358.

Niu, G. and D.S. Rodriguez. 2007. Heat and drought tolerance of selected bedding plants. Proc. of Southern Nursery Association 52:84-88.

Niu, G. and D.S. Rodriguez. 2008. Responses of growth and ion uptake of four rose rootstocks to chloride- or sulfate-dominated salinity. J. Amer. Soc. Hort. Sci. 133:663-669.

Niu, G., D.S. Rodriguez, and L. Aguiniga. 2007. Growth and landscape performance of ten herbaceous species in response to saline water irrigation. J. Environ. Hort. 25:204-210.

Niu, G., D.S. Rodriguez, and L. Aguiniga. 2008. Effect of saline water irrigation on growth and physiological responses of three rose rootstocks. HortScience 43:1479-1484.

Reed, D. 1996. Water, media, and nutrition for greenhouse crops. Ball Publishing, Batavia, IL.

SAS Institute. 2002. SAS/STAT software. Version 9.1. SAS Institute, Cary, NC.

Schuch, U. 2005. Effect of reclaimed water and drought on salt-sensitive perennials. HortScience 40:1095 (abstract).

Scoggins, H.L. and M.W. van Iersel. 2006. In situ probes for measurement of electrical conductivity of soilless substrates: Effects of temperature and substrate moisture content. HortScience 41:210-214

U.S. Environmental Protection Agency. 1983. Methods of chemical analysis of water and wastes (EPA-600/4-79-020). U.S. Gov. Print. Office, Washington, DC.

Wu, L., X. Guo, and A. Harivandi. 2001. Salt tolerance and salt accumulation of landscape plants irrigated by sprinkler and drip irrigation systems. J. Plant Nutr. 24:1473-1490.

Zollinger, N., R. Koenig, T. Cerny-Koenig, and R. Kjelgren. 2007. Relative salinity tolerance of intermountain western United States native herbaceous perennials. HortScience 42:529534. 